\title{
THE GROTESQUE AND MYTH IN GIAMBATTISTA BASILE'S IL PENTAMERONe
}

Antonela Marić, Filozofski fakultet Sveučilišta u Splitu, antonela@ffst.hr

Marko Dragić, Filozofski fakultet Sveučilišta u Splitu, mdragić@ffst.hr

Ana Plavša, Filozofski fakultet Sveučilišta u Splitu, aplavsa@ffst.hr

Original scientific paper

DOI: 10.31902/fll.36.2021.9

\begin{abstract}
This paper, besides a short introduction concerning general information on themes and the structure present in the short story collection $L o$ cunto de li cunti overo lo trattenemiento de' peccerille, written by the Italian Baroque author Giambattista Basile, whose masterpiece enjoyed great fame abroad much earlier than in Italy, is concerned with the analysis of fantastic and grotesque elements which generally characterise oral tradition, fairy tales and myths. The above-mentioned elements were identified in the fifty short stories which Basile wrote and included in his collection. Various sources were used in the analysis, relying on myths and fairy tales with the aim of explaining the presence of the grotesque. Besides its great literary value, this collection is also of great historical importance because, just like many other examples of oral tradition, it fosters a vast span of costumes and traditions that are typical of the Mediterranean folklore. From one tale to another, the collection slowly but surely reveals the Mediterranean identity of the people from the South of Italy and explains the function of the grotesque and its didactic purpose.
\end{abstract}

Keywords: fairy tales, fantasy, folklore, grotesque, magic, myth, tradition

\section{Introduction}

Giambattista Basile $(1994,26)$ claims in his introduction to Lo cunto de li cunti that there is no greater pleasure than the one of listening to amusing stories and anecdotes from somebody else's life. According to Michele Rak $(2005,2)$, a literary critic and translator of Basile's masterpiece, Basile's fairy tale collection is a captivating mixture of fantasy and folklore which thrives with elements of Italian commedia dell'arte. This precious collection provides the possibility to follow and analyse the genesis of the fairy tale, literary genre which was thoroughly 
redefined only in the $18^{\text {th }}$ century. Giovanni Francesco Straparola ${ }^{1}$ and Giambattista Basile were amongst the first European authors to introduce magic elements and fantasy in tales, whereas almost a century later Charles Perrault published Histories ou Contes du temps passé avec des moralités, which celebrated the so-called "Mode de fees"; i.e. a trend of a fairy tale that became popular among the aristocracy at the court of Louis XIV. Finally, in 1812 a fairy tale was identified as a genre which stemmed out from the oral tradition of storytelling (Gatto Trocchi 9 - 10).

Nowadays, there is a widespread tendency to associate fairy tales with children's literature because fairy tales depict reality "in a manner which conforms to the way a child thinks and experiences the world" (Bettelheim 45). However, it must be noticed that both fairy tales and folktales, regardless of the fact that they stem from oral tradition, abundantly rely on fantastic elements and magic which is combined with real-world settings, facts, and historical elements to convey convincing images to the audience. ${ }^{2}$ Some of the tales that are going to be tackled in this paper had originally been intended for adult audiences, which could explain the presence of the grotesque elements, allegories, sexual allusions, puns, and metaphors. Gradually, due to changes in literary and theoretical approach, scientific settings, social and literary context, such tales were redefined and transformed into classic examples of children's literature. Besides providing entertainment to its audience, they also tend to reveal national traditions and costumes, simultaneously performing a pedagogical function, i.e., they contain morals that had been passed from one generation to another, thus keeping alive the stories and legends. Fairy tales, therefore, preserve people's creed, wisdom, and values, which are summarised in a proverb or a moral that

\footnotetext{
${ }^{1}$ Giovanni Francesco Straparola included fantastic elements in his masterpiece, Le piacevoli notti, switching from the realistic tale typical of Boccaccio, to fantastic elements and imaginary characters that recalled One Thousand and One Nights or Panchatantra (Bellonci and Petrucciani 20-21). Basile also opted for the fantastic motives, imaginary places and allegoric situations, which enabled him to express himself freely and light-heartedly, without being judged or asked for any justification. Rak (6) highlights the allegory as one of the essential elements of fairy tales.

${ }^{2}$ Although the theoretical approach to fairy tales is rather prolific, for the purpose of this paper we shall mention Bettelheim's approach (59) supporting Freud's psychoanalytical attitude towards fairy tales, comparing them to dreams, which need to be repeatedly analysed just like fairy tales that are frequently reread to children in order to let them grasp a deeper symbolic meaning.
} 
is revealed and confirmed at the end of a tale, and according to which good always wins over evil, degeneracy and evildoings are punished, altruism and charity are rewarded, etc. While studying the Russian fairy tale, Vladimir Propp ${ }^{3}$ (21) notices that, besides the above-mentioned pedagogical function which most of the fairy tales have in common, there also seems to exist an identical plot structure employed by the narrators and followed by the characters, who seem to cover the same functions generally, within various tales. These functions, which are always attributed to the same type of characters, serve as stabile and constant components of a fairy tale. As Italo Calvino (5) claims in the Introduction to his Italian Folktales (a fairy tale collection from 1956), the habit of recounting the so-called novelline emerges much earlier on the Italian soil, more precisely in the Southern Italy, than in the rest of Europe, because its inhabitants had been exposed much earlier to the influence of the Arabian culture and its rich oral tradition, in respect to other nations.

However, this paper shall focus on the collection Lo cunto de li cunti overo lo trattenemiento de' peccerile 4 or II Pentamerone written by Giambattista Basile (under the alias Gian Alesio Abbattùtis), a prominent literate from Naples (later nicknamed the "folktale hunter"5).

The collection was initially published in 1634 by Ottavio Beltrano (editor), and subsequently defined by Thomas Crane (22) as a unique monument of folktales in Europe, inspired by the regional folktales. Despite belonging to popular culture, the collection was intended primarily for the Court, and it aimed at entertaining, or making the courtiers laugh by involving them into conversations about various legends, stories, etc. The collection managed to preserve the traditional

\footnotetext{
${ }^{3}$ In Morphology of the Folktale, Vladimir Propp (13) examined the methods used in various studies carried out by ethnographers and experts such as Alexander Afanasyev, Wilhelm Wundt, Antti Aarne, etc., challenging the lack of the precise classification scheme of fairy tales, insisting that the scheme is necessary to define [...] "relationships of tales among themselves (65)."

${ }^{4}$ Benedetto Croce was the first to translate the book in 1925. Subsequently, followed other translations in Italian. All quotations it the text that follows are extracted from Basile, Giambattista. 1994. II racconto dei racconti. Milano: Adelphi.

${ }^{5}$ According to the documentary series entitled "Città Misteriose", directed by Luca Trovellesi Cesana, Basile is frequently called the "folktale hunter" (cacciatore alle fiabe) because he spent most of his life collecting and writing down stories from oral tradition in the Campania and Basilicata regions located in the south of Italy (Trovellesi Cesana 2015).
} 
folk elements, elements of the genuine Mediterranean spirit, parody, comedy, and the grotesque.

\section{Basile's II Pentamerone or Lo cunto de li cunti}

Il Pentamerone or Lo cunto de li cunti overo lo trattenemiento de' peccerille is a collection of fifty short stories, narrated by ten narrators in five days. The collection imitates the structure of Boccaccio's masterpiece The Decameron. It is included in the narrative framework, typical of medieval tales, but contrary to Boccaccio's framework which was inspired by the deadly plague pandemic that struck Europe, and Florence in particular, Basile's framework is based on a fictious love story between the Princess Zoza and Prince Tadeo ${ }^{6}$. All the tales are

\footnotetext{
${ }^{6} \mathrm{~A}$ king from Vallepelosa had a daughter named Zoza, who never laughed. The king was desperately searching for a way to make her laugh, but with no success: he invited various jesters, played tricks, sought remedies, but all his efforts were in vain. In his last attempt, he decided to build a big fountain in front of the castle that was pouring oil instead of water so that people might slip and fall and eventually make Zoza laugh. One day an old woman was filling a jug with the oil when suddenly a mischievous boy from the court threw a stone at the jug thus breaking it into a thousand pieces. The woman started swearing and yelling at him and eventually she ended the fight by showing her genitals to the young fellow. Consequently, Zoza burst into laughter. The woman got angry and cursed Zoza by telling her that she would never be able to marry anyone except Prince Tadeo, who had been bewitched and doomed to sleep forever in a tomb at the entrance of Camporotondo unless a woman cried out a jar full of tears for him in three days. Only such a woman would wake him up and become his wife. Zoza was so desperate that she decided to head towards Camporotondo and not to miss her last chance of getting married. On her way to the town she met three fairies that felt sorry for her and gave her hazelnuts and chestnuts, advising her to open them only in case of an emergency. Zoza was so determined that she quickly found the prince's body together with a jug beside it and in less than two days she almost filled the jug with her tears. She was so tired that she fell asleep. While she was asleep a Moorish female slave bumped into her and, with no hesitation, took the jug, added just a few teardrops and woke the prince up from his sleep. He married her straight away and soon after she got pregnant. Seeking to correct injustice, Zoza moved into a house that was near Prince Tadeo's castle, making his wife jealous of her beauty and her precious objects which she had miraculously obtained thanks to the fairies' spells. Due to the last spell that was cast on her, the Moorish slave had a strong desire to listen to short stories until her baby was born. Since his pregnant wife's desires needed to be fulfilled, the prince had no time to waste, so he invited ten women from town. Each of them was supposed to recount one story per day within five days. The last story was
} 
narrated within five ${ }^{7}$ days by ten narrators from middle class backgrounds, except for the Princess Zoza who was of noble origins, but chose not to reveal it until the end.

Even though both authors were inspired by the Italian oral tradition, contrary to Boccaccio's tales concerned mainly with everyday reality, Basile's tales are based on unrealistic events and characters that can frequently be found in myths or fairy tales (Imbriani 1994, 617). Boccaccio's characters depict a realistic medieval world and develop real personality traits thus giving the reader an insight into genuine traditional elements, beliefs, and everyday life (Bellonci 9).

While reading II Pentamerone, one can easily come across characters such as ogres, fairies, elves, enchanted princes and princesses, animals with human characteristics, etc. Such characters can be found in books of many fairy tale writers who succeeded Basile, such as Carlo Gozzi, the Brothers Grimm, John Edward Taylor or even in Disney's contemporary animated films. In 2015, in the most recent film adaptation of Basile's tales, Matteo Garrone, a famous Italian film producer and director, adapted three tales full of grotesque and fantastic elements from II Pentamerone: The Enchanted Doe, The Flea, and The Flayed Lady ${ }^{8}$.

recounted by Princess Zoza so as to reveal the truth to Tadeo. When he discovered the truth, Tadeo killed the slave and married Zoza.

${ }^{7}$ This is the reason why this masterpiece is also called /I Pentamerone. However, it is a well-known fact that symbolic meanings were often attributed to numbers and they used to play an important role in terms of the establishment of cosmos. Therefore, it is not surprising that they are present in myths, fairy tales and folktales where there is a clear tendency to mix realistic and abstract elements as well as mystical and profane ones. In his work, Basile uses mostly the following numbers: $3,5,7,10$, and 50 . Besides giving to his work a solid structure, some of these numbers are used symbolically. For example, within the collection there are numerous repetitions of numbers: e.g., a king has seven sons who marry seven sisters, and they live together in a perfect harmony behind seven mountains, etc. Number seven, which is also frequently present in the modern varieties of fairy tales and animated films, represents perfection $(3+4)$, i.e., "a combination of an even and an odd number", and in terms of religion it symbolises "gifts of the Holy Spirit: relaxation, Easter and Salvation" (Brach 48).

${ }^{8}$ Garrone's film Tale of Tales was released in 2015 and competed for the Palme d'Ore at the Cannes Film Festival. The film, produced by Rai cinema in English language, is an adaptation of the three above mentioned stories from Basile's masterpiece. The film abounds in fantastic and elements of horror, typical of Garrone's cinematography. Garrone managed to convey Basile's genuine grotesque features combined with the folklore and the macabre. Garrone 
It is interesting to notice that within Basile's collection there are fairy tales that later assume various forms in numerous cultures and in many different languages, such as: La Gatta Cenerentola (Cinderella), Petrosinella (Rapunzel), Cagliuso (Puss in Boots), Sole, Luna e Talia (Sleeping Beauty), Ninnillo e Nennella (Hansel and Gretel), etc.

The original collection of Lo cunto de li cunti was written in Neapolitan and was published posthumously. However, it became famous in Italy and all over Europe only in the $18^{\text {th }}$ century, after it had been translated into foreign languages and into standard Italian. The Brothers Grimm expressed particular interest in Basile's folktale collection. In particular, Jacob Grimm praised Giambattista Basile for his originality and talent in the critical essay Kinder- und Hausmärchen (Imbriani 1994, 635). The Brothers Grimm translated and adapted the tales $^{9}$ in order to make them more appealing to children, eliminating the majority of the grotesque and horror elements.

Even though according to its subtitle, Overo lo trattenemiento de' peccerille, Basile's collection seems to be aimed at children's entertainment, numerous Basile's critics and translators, including Giambattista Basile himself, would not agree with such a statement, because the tales are full of dark, grotesque, and sometimes even gruesome details. As a matter of fact, Benedetto Croce (1994, 659-661) claimed that Lo cunto de li cunti was not just a folktale collection, but also a hidden treasure that preserved costumes and traditions of the vivid Neapolitan folklore from Basile's epoque. Furthermore, due to its symbolism, Croce also confirmed that the collection was aimed at adults' entertainment rather than the children's. For example, the character of the ogre's wife, besides its principal function of causing fear in other characters, may also symbolise a stereotype of a vengeful woman from the area of Naples that in one of the scenes becomes jealous of her neighbours and, therefore, does not want to see them in

decided to explore Basile's world convinced it was a mixture between reality and fantasy, claiming that these elements have always characterised his artistic research. "[...] The stories told in the Cunto de li cunti (Tale of Tales) recall the opposites in life: the ordinary and the extraordinary; the magical and the everyday; the regal and the dark; the simple and the imagined; the sublime and the filth; the terrible and the sweet; scraps of mythology and torrents of popular wisdom. The tales narrate human emotions pushed to extremes." Garrone, Matteo. "Tale of Tales: introduction notes." Archimede, [n.d.], https://www.matteogarrone.eu/filmografia.php?tag=filmografia\&idscheda= 93\&tipologia =film\&titolo=TaleofTales\&lang=en . February 20, 2021.

${ }^{9}$ Numerous adaptations and translations followed shortly afterwards, such as those by Liebrecht, Taylor, etc. (Croce 1994, 664). 
her garden, and in another, she could be having an ordinary conversation with her husband while having dinner together. This is a clear sign of interaction between the fantastic and the ordinary. Another interesting example is the story about Sapia's sisters who symbolise the untameable nature of the Mediterranean girls from Naples because they run away into their lovers' arms, thus opposing their own will to their father's strict regime of praising chastity above everything. Finally, in the tale Cinderella the Cat, Basile compares Cinderella's parade with a courtesan that is accompanied to prison by the police, etc. (Croce 1994, 662). Moreover, the fact that the tales contain vulgarisms and sexual allusions, confirms the hypothesis according to which Basile's tales had originally been written for adults. The same hypothesis is confirmed by the presence of the four complex eclogues, serving to end and conclude each of the first four days, full of images, symbols and metaphors by means of which Basile criticises human dishonesty, envy, and greed.

\section{Elements of fantasy, grotesque, and magic in Lo cunto de li cunti}

The elements of fantasy and grotesque ${ }^{10}$ intermingle with magic and enchantment throughout the entire Basile's collection. Propp, in his

\footnotetext{
${ }^{10}$ According to Gino Gori, the grotesque elements belong to the sphere of fantastic, incredible, and incompatible with the reality. The author considers the grotesque as separate forms derived from the individual experience. Furthermore, Gori $(1927,10)$ explains the concept of the grotesque by highlighting the contrast ideal-real. For him, the grotesque is the artistic form which "denies the laws of nature", depending on the artist's imagination (for example, in literature) and his ability to convey emotions respecting the absolute freedom of the spirit.

The grotesque is (by some) perceived as the articulation of humour, satire or caricature, or the combination of all the said forms. Philip Thompson (3) suggests that before any attempt to define the grotesque, we must recognise that "the grotesques have no consistent properties other than their own grotesqueness, and they do not manifest predictable behaviour." For G. R. Tamarin (133), there is no precise definition of the grotesque, as well. He considers it more a model, rather than a content, arguing the potential of the content itself. Tamarin considers the tragicomic category as the closest to the grotesque, adding to it also "the cerebral." (The concept of "the cerebral" thus added to the grotesque, in our opinion, might be closest to Pirandello's concept of humourism). Tamarin divides the grotesque in intentional and unintentional, and highlights the relevance of masks to masquerade the manifestations of distortion, disharmony and grotesque grimacing. He also warns about the presence of the fantastic in the grotesque. According to this author, the grotesque would greatly rely on the means of decomposition and disharmony.
} 
work Morphology of the Folktale, highlighted the necessity to analyse and compare fairy tales by respecting the order within the proposed structural scheme. According to the Russian literary critic (46), the fairy tales are categorised and analysed morphologically, i.e., they are described according to the predetermined components and their interrelations.

In Basile's tales, we can easily identify many of the narrative units or functions ${ }^{11}$ identified by Propp. A vast majority of Basile's tales end with a wedding which is frequently preceded by the punishment of villains that might have been an obstacle, as it happens in the tale The Myrtile $^{12}$. The tale confirms the presence of the assentation function, as

For the purpose of this paper, without entering into a more detailed definition of the grotesque, we shall accept and make use of Wolfgang Kayser's (188) "attempt to define the nature of the grotesque." The grotesque, according to Kayser (197), besides being an esthetic category referring to creative attitudes, must consider the effect of the creative process, the work of art itself and its reception. The grotesque, by playing with the absurd, represents "an attempt to invoke and subdue the demonic aspects of the world." In other words, in order to be defined as the grotesque, the elements of a work of art must satisfy these requests.

${ }^{11}$ Propp establishes 31 narratemes or narrative units and not all of them are necessarily present within the same tale, but there is always at least one of them in every fairy tale: 1) assentation, 2) interdiction, 3) violation of interdiction, 4) reconnaissance, 5) delivery, 6) trickery, 7) complicity, 8) villainy and lack, 9) mediation, 10) counteraction, 11) departure, 12) testing, 13) reaction, 14) acquisition, 15) guidance, 16) struggle, 17) branding, 18) victory, 19) resolution, 20) return, 21) pursuit, 22) rescue), 23) arrival, 24) claim, 25) task, 26) solution, 27) recognition, 28) exposure, 29) transfiguration, 30) punishment, 31) wedding (Pozzato 22-23). Propp furthermore (64) claims that "[...] if we read through all of the functions, one after another, we observe that the function develops out of another with logical and artistic necessity. We see that not a single function excludes another. They all belong to a single axis and not, as it has already been mentioned, to a number of axes." Upon a detailed analysis of the tales, the conclusion arises that all the afore mentioned narrative units could be easily identified in the collection.

${ }^{12}$ The story evolves around the hopeless desire of a couple to have children. The desire was so strong that the wife wanted to become a mother at every cost, even if it meant giving birth to a branch of myrtle. Her desire eventually came true. One day a prince saw the myrtle and he was so enchanted by its beauty that he desperately begged to have it. Finally, after having promised to take proper care of it, he obtained it and placed it into his bedroom. During the night the branch turned into a beautiful fairy. Before leaving the fairy to go hunting, the prince put a small bell around the fairy promising to wake her up by pulling the thread once he was back home. While the prince was away, seven 
suggested by Propp, since the prince leaves his bedroom to go hunting; as well as the violation of interdiction (because somebody touches his plant while he is away). An example of trickery can be identified in the tale entitled The Merchant in which one of the protagonists named Cienzo is tricked and trapped by a fairy, until his brother Meo comes and saves him. Fairies seem to perform contradictory functions because in some tales they help heroes or people in trouble while in the others they cast spells or trick young men with their enchanting beauty. It is interesting to notice that the punishment function is present also within the narrative framework. Namely, prince Tadeo punishes the Moorish slave by killing her and the baby. Most of the tales deal with the motif of good winning over evil, so there are numerous scenes of struggle in which protagonists defeat enemies, such as supernatural creatures and dragons, as in the tale The Enchanted Doe.

Magic $^{13}$ is a common ingredient of every fairy tale, therefore, Basile uses magic abundantly and in quite an effortless manner, by immerging the reader into an enchanted world of mysterious woods, fairies and elves, ogres, princes, and princesses, thus enabling them to break free, and suspend any thought of seeking logic or reality in the stories.

evil girls sneaked into his bedroom, touched the branch, and woke the fairy. The girls then killed her out of jealousy. The story ends with a miraculous rebirth (thanks to the scattered leaves that a servant placed inside a vase), subsequent execution of the evil girls, and the marriage of the prince and the fairy.

${ }^{13}$ According to Michele Rak (158), Italian literary critic and writer, in creating magical components of the tales, especially those in which characters were changing their shapes, gender or nature, suggesting the appearance of chimeric creatures and metamorphs, Basile was actually under the influence of the Baroque theatre which was characterised by masking and disguise. These moments of disguise meant gaining freedom and breaking free from social expectations and norms.

An interesting explanation related to masking and the Italian commedia dell'arte is offered by Wolfgang Kayser in which he claims that masking in the commedia adds animal qualities to the body, with excessively long extremities, bodily parts, feathers, etc. The exaggeration seems to be the main feature of the grotesque and chimeric world present in the commedia (Kayser 37-47). Speaking of theatrical pieces, there have been some manifestations of the grotesque in both comedies and tragedies. One of the most interesting phenomena is undoubtably the Italian grotesque theater, at the beginning of the 20th century, with its many features and manifestations. For a comparison of some grotesque features in Italian and Croatian dramas, please refer, amongst other, to the paper exploring the inter-and intratextual features of the said authors belonging to the Mediterranean circle (Marić 243-261). The same grotesque characteristics can be applied to Basile's tales, as well. 
However, this magic, which initially might look like an escape from a harsh reality, actually performs a pedagogical function. It punishes vanity, envy and negligence, and rewards humbleness, patience, and modesty.

The question that arises at this point is concerned with the real purpose and the function of magic in Basile's tales. Certainly, the purpose is not to awake the imagination nor to entertain children, but to convey the symbolic meaning. Through symbolism, Basile gives an insight into some fundamental problems that characterised the society of the time, such as the conflict between the lower and upper class, unfaithfulness, promiscuity, lust, jealousy, extravagance, fear of growing old, etc. The allegorical function of a fairy tale is highlighted in particular at the very end, summing up (it could be in a form of a proverb) the allegorical meaning of the tale itself. A fairy tale reader does not question the truthfulness of the narrated events. According to Pirandello (119), a truly talented author never steps back from his or her fantastic world while narrating, and he/she believes in it until the end of the story.

Both the fantastic and the magical belong to the sphere of the unreal (even surreal). For that reason, while reading II Pentamerone, the reader inevitably comes across the exaggerated shapes, descriptions of grotesque and ugly creatures and animal-like human beings, who sometimes assume deformed, even chimeric physical appearances. Bakhtin (19) in Rabelais and His World, claims that the grotesque is characterised by "[...] degradation, that is, the lowering of all that is high, spiritual, ideal, abstract; it is a transfer to material level, to the sphere of earth and body in their indissoluble unity."

Such an example is particularly highlighted in the tale The Goat Faced Girl, in which a fairy turns Renzolla's face into a goat due to her ungratefulness. This is a situation that might initially make one laugh, but gradually, it evokes empathy, and makes the reader pity the young woman. Eventually, the relief is brought in the moment when she repents, and the magic is undone. The grotesque can also be identified in the tale entitled The Flea in which the king from Altomonte grows a giant flea by letting it suck his blood every day, promising to give his daughter's hand to a man that guesses what animal it is. Sadly, a hideous ogre guesses the name of the animal thus winning Porziella's hand. The surreal moments and unreal creatures resemble the Bakhtinian concept of the carnivalesque. In this case, the presence of masks and masquerade allowed in particular the members of the aristocracy to forget about the etiquette, rules and restrictions and to enjoy the same sense of freedom which normally can be felt during the carnival parades. 
Bakhtin (34) explains that the carnival-grotesque elements "consecrate inventive freedom and [...] permit the combination of a variety of different elements and their rapprochement", thus offering the reader a new perspective contrary to the existing clichés and the universal truths. In order to highlight the presence of the grotesque, Bakhtin (32) quotes Pinsky who describes grotesque in art as something that at first sight might seem "merely witty and amusing, but it contains great potentialities" to be further elaborated and contemplated upon.

There are numerous other examples of almost surreal grotesqueness in /I Pentamerone, such as the moment in which a character gives birth to a branch of myrtle, or when another character gets pregnant having eaten a dragon's heart, and yet another eats a branch of roses. There is also the example of a cursed baby girl born with a bunch of parsley growing out of her bosom; a story about Penta who refuses to marry her widowed brother and asks a slave to cut her hands off, and to send them to her brother who is obsessed with them; a woman that has her skin flayed in order to look younger; a prince that cuts his finger while eating and is enchanted by the beauty of the red blood on ricotta cheese, which evokes a desire in him to marry only a woman of these colours; unreal animals such as a duck pooping golden coins or a rooster with a precious stone inside its head, etc. As it has previously been stated, the function of the macabre and the grotesque elements, is highly relevant, having as objective to liberate both the author and his audience from the court etiquette. Through the use of metaphors, the author has the opportunity to speak about social issues such as incest, prearranged, contracted marriages, shallowness, infertility, materialism, obsession with physical appearance, etc.

Another recurring grotesque motif present in Basile's collection is madness, frequently elaborated also by the afore quoted Pirandello. Let us only think of Henry IV, or One, No One and One Hundred Thousand, perceiving and rehabilitating madness as a legitimate form of (both real and mental) life. Madness and subconscious characterise the majority of the grotesque forms and provide a different insight into the world considered distant from what is usually perceived as normal or ordinary (Bakhtin 63). Laughter frequently follows the appearance of such characters, who are then commonly considered different, strange, sometimes ridiculous. Eventually, as mentioned earlier, one comes to empathise with them. One such character is Vardiello whose naivety or gullibility is, on some occasions, hilarious while on the others, it makes one reflect upon situations in which his good nature is exploited. Moreover, grotesque elements are also revealed in Basile's witty use of language. Throughout his stories the author frequently makes analogies 
and puns in order to refer to a phallus or to sexual intercourse itself, thus provoking laughter. For example, in the story The Flayed Lady the king sings a song to his lover, asking her to welcome his falcon. Such images of "the lower stratum" were a typical characteristic of humble and simple folk, as well as their frequent use of coarse and swear words (Bakhtin 111). ${ }^{14}$ In many of Basile's tales, just like in numerous myths, there is a protagonist whose function is to eliminate chaos and to establish cosmos, and therefore, to provide a fairy tale with a happy ending upon which "everybody lived happily ever after". A protagonist, just like Ulysses and many other ancient Greek heroes, frequently makes a mistake and is consequently forced to estrange from everybody in order to finally establish cosmos and to find his true self. One such example can be identified in the tale The Enchanted Doe in which the protagonist Fonzo is miraculously born thanks to magic. He was conceived because his mother, the queen of Lungapergola, ate a dragon's heart cooked by a virgin. As a result, both the queen and the virgin, gave birth to a son. The boys were identical, but with different destinies, because one was brought up in prosperity inside a beautiful castle, while the other lived in harsh poverty. Fonzo made friends with his half-brother Canneloro and since the queen did not approve of it, she banished Canneloro from her kingdom. Obviously, the protagonist will break the rules as soon as he finds out that his half-brother is in danger. When Fonzo sees the muddy water in the fountain, he interprets it as a sign that his half-brother is in trouble and goes to seek

\footnotetext{
${ }^{14}$ Bakhtin (16) claims that: "It is characteristic for the familiar speech of the marketplace to use abusive language, insulting words or expressions, some of them quite lengthy and complex. The abuse is grammatically and semantically isolated from context and is regarded as complete unit, something like a proverb. [...] Abusive expressions are not homogeneous in origin; they had various functions in primitive communication and had in most cases the character of magic and incantations". Basile's witty use of such language creates comic situations and simultaneously reveals rather coarse manners which characterised people who belonged to the lower social class. Furthermore, the use of (what by "language purists" might be defined as) taboo, dirty, lurid, or swear words, is commonly considered typical of demonic or satanic presence, which could contribute to the atmosphere of the grotesque. Namely, it is not uncommon in literature to interlink the "lower" register, or some incomprehensive language (from Dante to the present day), to demonic, to enchantment, basically to primitive lower strata, believed to be engaged in witchcraft and magic.
} 
him, abandoning his comfort zone in order to establish cosmos by saving his brother from the jaws of a monster.

Numerous features, typical of myths, as suggested by Propp (43), can be traced, as follows: the protagonist is born due to a miracle; the hero, neglectful of the rules, aims to perform a good deed; then follows the phase of alienation; and finally, thanks to his supernatural powers, he manages to defeat the monster, save his half-brother, and give him the possibility to live with his family in tranquillity.

Another characteristic of a myth in Basile's tales, is the pattern of death and rebirth. This example can easily be identified in the introductory tale in which the prince is bewitched and brought back to life thanks to Zoza's tears. In many other tales in the collection, the heroes are also brought back to life thanks to magic. Therefore, very frequently a hero "mortem moriendo destruxit, vitam resurgendo reparavit" (Buttitta 223). A hero is courageous, or awarded to the extent that he manages to defeat the death itself. Furthermore, the miraculous (re)birth is yet another element that can frequently be associated with the heroic grotesqueness (e.g., a virgin gives birth to a son, a mother who, instead of a child, gives birth to a branch of myrtle, etc.).

Finally, the transformations into reptiles, frequently into snakes, are recurring in myths. Shapeshifting heroes confirm the presence of the grotesque, which amongst others can be characterised by the deformed, twisted and multishaped zoomorphic creatures, by the bizarre, opposition/contraposition or negation of what is usually perceived as natural, and commonly acceptable, as well as by over- or supra- dimensions, horrible and immoral. As Buttitta (223) claims in Mito fiaba rito ${ }^{15}$, in Greek mythology even Zeus appears in the form of a snake. A snake does not necessarily represent evil, as it is commonly interpreted. On the contrary, it can symbolise a wrongful perception of a hero, who appears in the form of a snake in order to hide his real nature. Such an example can be found in the tale The Snake, which has its numerous versions in different parts of Italy. In this tale, the protagonist is snake-shaped at birth, but after his wife's parents burn his snakeskin, which he used to take off only before his wife, he transforms into a dove. The wife was the only one that knew his true nature and, therefore, she was the only one that eventually managed to save him.

15 This paper embraces Bronislaw Malinowski's (1926) anthropological approach to myth, insisting that myths cannot be tackled without examining social contexts, from the very primitive to the current ones, by combining the religious to the ethical and deontological. The myth is perceived as the essential ingredient of civilisation that contributes to shaping of the reality. 
The fact that there are more varieties of the above cited tale confirms the hypothesis according to which every fairy tale is a simplified version of an earlier and more complex story (Buttitta 222).

\section{Basile's recognisable style}

Benedetto Croce is one of the most famous translators of Basile's tales in standard Italian. In his preface to the translation of II Pentamerone dated in 1925, Croce states that it was complicated to reduce Basile's rich writing style narrated in Neapolitan and to give it a new form using the standard Italian. Croce $(1994,666)$ came across numerous mistakes concerning the syntax while he was reading $L O$ cunto. Still, he decided to remain as faithful to the original as possible with the aim of preserving the genuine spirit of Naples and the neighbouring regions, and its simple, humble people.

Moreover, Calvino (5) names Basile the Neapolitan Shakespeare because of the rich Baroque style he used to shock his readers with, i.e., the combination of an elevated style and vulgar elements, a concept typical of the Baroque authors. All Basile's tales have in common the socalled flat characters, similar setting, the same introductory sentence ("C'era una volta..."), typical of fairy tales, a lack of logic in situations such as the ones in which the protagonist is brought back to life thanks to the use of spells and magic, etc. These elements can be identified in most of the fairy tales we are familiar with nowadays.

The feature that distinguishes Basile from other authors, besides his rich imagination, is his vivid narrative style. Being a Baroque writer, Basile's style is characterised by rich vocabulary, complex sentences, exaggerated and sometimes bizarre use of images, decorations, metaphors, symbols, excessive use of diminutives, etc. In each of the fifty short stories in Lo cunto de li cunti, Basile uses language in a unique and recognisable way, listing up to ten adjectives in a row (common Baroque language decorations) in order to describe a particular situation in a trustworthy manner. Such style of storytelling can be attributed to the influence of oral tradition from which the tales derive, but also, it could have been a mere thirst for exaggeration and embellishment. An example of adjective sequencing, typical of oral tradition, simultaneously serving as the confirmation of the grotesqueness, can be seen in the tale The Bear, in which the king from Rocca Aspra has no success in finding a new wife after the queen's death. None of the girls manage to meet his criteria of ideal beauty:

[...] e adocchiando e squadrando questa e quella, una gli pareva storta di fronte, una lunga di naso, chi larga di bocca, chi grossa di labbra, questa una lungagnona, quella una corta malfatta, chi 
troppo gonfia, chi eccessivamente gracile; la spagnola non gli piaceva per il colore smorto, la napoletana non gli andava a genio per i trampoli sui quali cammina, la tedesca gli sembrava fredda e gelata, la francese di cervello troppo sventato, la veneziana una conocchia di lino, coi capelli così bianchicci [...] (Basile 1994, 226)

The girls are deformed, and have big noses, wide mouths or big lips; they are either tall or small, swollen or skinny; sometimes too fair in complexion, long legged, etc. There are also some stereotypes about Spanish, German and French girls that seem rather naïve; the Venetian who looked like a cotton spindle with the whiteish hair, and similar. Again, the exaggeration and the deformity of the body, including the picturesque descriptions, suggests the perception of the grotesque as fully opposed to the appealing, by the selection of various figures of speech. The grotesque is present even in the descriptions of nature, in contrasts, and through metaphors and personifications. Another characteristic of the recognisable Basile's writing style is his imaginative, symbolic, and slightly grotesque choice of characters' names and the use of puns, as well as the frequent presence of sexual allusions. For example, the name of Princess Zoza could be easily associated with the Italian adjective "zozzo" which means "dirty/vulgar". There are also interesting and detailed descriptions of woods, magical worlds of fairies and elves, princes and princesses, as well as the presence of strong emotions that vary from one tale to another. Some tales, expectedly, can make one cry with laughter, while others might bring one to a rather depressive mood, and make one sympathise with the fictitious characters.

According to Calvino (10) every fairy tale, no matter where it comes from, assumes the characteristics of the nation which recounts it, whether in terms of costumes, traditions or values. Basile's Neapolitan idiom, used for /I Pentamerone has very little in common with the standard Italian. However, this dialect managed to conserve the genuine microcosm of the Baroque Naples with all its costumes, traditions, folklore and primitive beliefs which characterise the nation whose knowledge is based on the experience of their forerunners.

Another feature of Basile's tales is the presence of superstitions, cursing and spell-casting mixed with religious rites, which could be related not only to the characters' social class, but could be well explained by the presence of anthropological and ethnological elements. 


\section{Conclusion}

Following the research of the grotesque features in the collection Lo cunto de li cunti, brought us to the conclusion that the collection abounds with fantastic and grotesque elements, including the unavoidable magic and enchantments to be found in oral tradition. Narrative units and sequences of events, typical of myths and fairy tales, have been identified following Propp's morphological analysis. What makes this collection special is the fact that it preserves earlier versions of fairy tales, famous nowadays, but neglected for years only because they had been written in Neapolitan. It may be concluded that Basile's fairy tales perform a pedagogical function, i.e., they give the reader an insight into norms and conventions of the Baroque society by using grotesque and fantastic elements, and supernatural characters. The grotesque features, furthermore, possess a didactic function of its own, making one feel humble and insignificant in comparison to the forces beyond one's powers. Simultaneously, through numerous grotesque characters and macabre episodes the author metaphorically speaks about social issues and problems that were considered taboos in Basile's lifetime, in a period characterised by the decorum established by the court. Even the collection itself, which at first seems to be intended for children, is a satirical and symbolic representation of the Baroque society. Lo cunto de li cunti is a precious collection which has preserved southern Italy's cultural and social identity. What distinguishes Basile's tales from the ones collected by the Brothers Grimm is the preservation of tradition and national identity. In Grimm's tales, the narrator sets imaginary characters into an imaginary world while Basile places his fictional characters into the real world. In time, after numerous adaptations, most of the elements tackling the national identity faded away, while the two elements that remained unchanged even today are the didactic function and the presence of the grotesque and the myth.

\section{Works Cited:}

Bakhtin, Mikhail. Rabelais and His World. USA: Indiana University Press, 1984.

Basile, Giambattista. I/ racconto dei racconti, edited by Alessandra Burani and Ruggero Guarini. Translated by Ruggero Guarini. Milano: Adelphi, 1994.

Basile, Giambattista. Lo cunto de li cunti, edited by Michele Rak. Milano: Garzanti, 1995.

Bellonci, Goffredo and Mario Petrucciani. Novelle italiane dalle origini al '900 (volume I/1). Roma: Lucarini, 1986.

Bellonci, Goffredo and Mario Petrucciani. Novelle italiane dalle origini al '900 (volume II/1). Roma: Lucarini, 1986. 
Bettelheim, Bruno. The Uses of Enchantment. The Meaning and Importance of Fairy Tales. New York: Vintage Books, 1975.

Brach, Jean-Pierre. Il simbolismo dei numeri. Roma: Eredi Edizioni Arkeios, 1999.

Buttitta, Antonino. Mito fiaba rito. Palermo: Sellerio, 2016.

Calvino, Italo. Fiabe italiane raccolte e trascritte da Italo Calvino. Torino: Einaudi, 1956.

Calvino, Italo. Mondo scritto e mondo non scritto. Milano: Mondadori Libri, 2015.

Città misteriose, documentary series, directed by Luca Trovellesi Cesana. 2015. Sydonia Production. Prime Video Amazon, 2021.

Crane, Thomas Frederick. Italian Popular Tales. London: Macmillan and Company, 1885.

Croce, Benedetto. Giambattista Basile e l'elaborazione artistica delle fiabe popolari in: Basile, Giambattista. II racconto dei racconti. Milano: Adelphi, 1994.

Croce, Benedetto. Introduction in Cunto de li cunti. Bari: Laterza, 1925.

Eco, Umberto. Simbolo. Bologna: Luca Sossella, 2019.

Garrone, Matteo. Tale of Tales: Production notes. Archimede, [n.d.], https://www.matteogarrone.eu/filmografia.php?tag=filmografia\&idsche $\mathrm{da}=93$ \&tipologia=film\&titolo=TaleofTales\&lang=en. February 20, 2021.

Gašparović, Darko. Kamov, apsurd, anarhija, groteska. Zagreb: Cekade, 1988.

Gatto Trocchi, Cecilia. Le più belle fiabe popolari italiane. Roma: Newton Compton, 2017.

Gori, Gino. Il grottesco nell' arte e nella letteratura. Roma: Alberto Stock, 1927.

Gori, Gino. Il mantello d'arlecchino. Roma: Tipografia editrice nazionale, 1914.

Harpham, Geoffrey Galt. On the Grotesque. Strategies of Contradiction in Art and Literature. Davies Group Publishers: Aurora, 2006.

Imbriani, Vittorio "Il gran Basile". Giornale napoletano di

filosofia e lettere. col. II. (1875): 429-59 in: Basile, Giambattista. I/ racconto dei racconti. Milano: Adelphi, 1994.

Kayser, Wolfgang. The Grotesque in Art and Literature. Bloomington: Indiana UP, 1963.

Lévi-Strauss, Claude. Antropologia strutturale. Milano: il Saggiatore, 2015.

Malinowski, Bronislaw. Myth in primitive psychology. New York: W.W. Norton \& Co.,1926.

Marić, Antonela. "Groteskni elementi u odabranim hrvatskim i talijanskim dramama s početka XX. stoljeća. Interpretacija i intertekstualnost". Lingua Montenegrina, 1 (21), (2018): 243-261.

Pirandello, Luigi. L'umorismo. Milano: Garzanti, 2001.

Pozzato, Maria Pia. Semiotica del testo. Roma: Carocci, 2020.

Rak, Michele. Logica della fiaba. Milano-Torino: Pearson, 2005.

Propp, Vladimir Jakovlevič. Morphology of the Folktale. University of Texas: The American Folklore Society, 1968.

Tale of Tales, directed by Matteo Garrone. Rai Cinema, Archimede, Le Pacte, Recorded Picture Company. Prime Video Amazon, 2021.

Tamarin, Georges R. Teorija groteske. Sarajevo: Svjetlost, 1962.

Thomson, Philip. The Grotesque. London: Methuen, 1972. 


\section{IL GROTTESCO E IL MITO NE IL PENTAMERONE DI GIAMBATTISTA BASILE}

Il presente contributo, oltre a una breve introduzione che contiene le informazioni generali sui temi e sulla struttura della raccolta Lo cunto de li cunti overo lo trattenemiento de' peccerille di Giambattista Basile, presenta un'analisi degli elementi fantastici e grotteschi che generalmente caratterizzano la tradizione orale, le fiabe e i miti. Gli elementi sopra elencati si possono identificare in tutti e cinquanta racconti che Basile è riuscito a raccogliere e includere nella raccolta. Nell'analisi è stato usato il cosiddetto metodo morfologico di Propp come anche le altre risorse il cui punto d'interesse sono proprio miti e fiabe. Oltre al suo grande valore letterario, la raccolta Lo cunto de li cunti ha una grande importanza storica, perché, come molti altri capolavori che si ispirano o provengono dalla tradizione orale, essa conserva tantissime usanze e tradizioni che sono tipiche del folklore mediterraneo, a partire dai giochi di carte napoletani alle canzoni tradizionali, riti e balli. Da una storia all'altra la raccolta svela l'identità nazionale del popolo del sud d'Italia e del Mediterraneo.

Parole chiave: fantasia, fiabe, folklore, grottesco, magia, mito, tradizione 